\title{
大型車いす使用者のトイレ利用動作と空間寸法に関する研究 STUDY ON LARGE-SIZED WHEELCHAIR USERS MOTIONS IN PUBLIC TOILET AND MINIMUM TOILET SPACE
}

\author{
高塩康 洋*, 高 橋儀平**, 河野裕之*, 前橋 信 之* \\ Yasuhiro TAKASHIO, Gihei TAKAHASHI, Hiroyuki KAWANO \\ and Nobuyuki MAEBASHI
}

\begin{abstract}
This study conducts verification experiments for a minimum measurement of restrooms for large-sized wheelchair users in a public toilet. From our inquiry, one of the most difficult task to a large-sized wheelchair user in a public restroom is to make a favorable approach to the toilet seat which requires switchback motions.

This verification experiments suggested that the space should be at least $90 \times 170 \mathrm{~cm}$ to $110 \times 150 \mathrm{~cm}$ in front of a toilet seat, and this would make more flexibility about designing a public toilet for large-sized wheelchair users, especially in renovating old facilities.
\end{abstract}

Keywords : Barrier-free, Public rest room, Wheelchair user, Wheelchair movement, Space Measurements バリアフリー，公共トイレ，車い寸使用者，利用動作 ，空間寸法

\section{1. 研究の背景 ·目的}

2006 年 12 月、「高齢者・障害者等の移動等の円滑化の促進に関寸 る法律」（以下、B F 法）が施行され、B F 法に係る建築物のトイレ の設備・空間要件として、「高齢者、障害者等の円滑な移動等に配慮 した建築設計標準 ${ }^{1 ）}$ (以下、建築設計標準)」が定められている。 2012 年 7 月改訂版の建築設計標準では、車い寸使用者用便房の標 準的空間寸法は $200 \mathrm{~cm} \times 200 \mathrm{~cm}$ 程度が望ましい、車いすが回転でき る空間は直径 $150 \mathrm{~cm}$ が望ましいと記されている。

筆者らは、近年、車い寸使用者のトイレ整備要望の高い小規模施 設や既存施設の改修においては、スペース的、構造的な制約等によ り標準的寸法 $200 \mathrm{~cm} \times 200 \mathrm{~cm}$ 程度を確保することは困難な場合が多 いという状況を踏まえ、標準的寸法が確保できない場合の次善策と して、小規模施設、既存施設の改修等への対応策の一手段として、 やや小さめでも車い寸使用者が利用可能な車い寸使用者用便房の必 要空間寸法の研究 3 ) を行った。

この研究 ${ }^{3)}$ により車い寸使用者は車い寸で回転ができないものの、 車い寸使用者が、特段のストレスなく車い寸を切り返すことで方向 転換および前進退室が可能な車い寸使用者用便房の必要空間寸法と して、「間口方向 $(\mathrm{Y}): 150 \mathrm{~cm}$ （便器前寸法 $110 \mathrm{~cm}) \times$ 奥行き方向 $(\mathrm{X})$ $180 \mathrm{~cm} 」 を$ 見出した。
しかしこの研究においては、被験者の車い寸サイズは全員が標準 サイズ (全長 $113 \mathrm{~cm}$ ) 未満の車い寸使用者が対象であり、多くの車 い寸使用者が利用可能な便房の必要空間寸法の決定過程においては、 車い寸の J I S 規格 ${ }^{4)}$ の最新版にある車い寸の最大寸法である全長 $120 \mathrm{~cm}$ 、全幅 $70 \mathrm{~cm}$ に近い、市場で使われている大型車いす使用者の 検証が課題として残されていた。

そこで本研究は、大型車い寸使用者注2）を被験者とした検証によ り、多くの車い寸使用者に利用可能な必要空間寸法を検討すること を目的とした。

\section{2. 研究の方法}

研究フローを表 1 に示す。本研究は以下の 3 点を課題とした。 (1)車い寸使用者がトイレ利用でポイントとなる動作の明確化

(2)トイレ利用動作のポイントを満たす必要空間寸法の明確化 (3)多くの車い寸使用者に利用可能な必要空間寸法の検討

S T E P 1 では利用者検証によるトイレ利用動作の観察・分析か ら必要空間寸法の明確化を行った。S T E P 2 では利用者検証に協 力いただいた被験者に対して研究結果について意見交換会を行い、 研究の狙い及び研究結果に対する利用者の評価を行った。 S T E P 3 では、多くの車い寸使用者に利用可能な必要空間寸法の検討を行 った。

\footnotetext{
$*$ TOTO (秼

** 東洋大学人間環境デザイン学科 教授・博士 (工学 $)$
} 
なお、車い寸使用者の利用動作は入室から退室までの一連の動作 を 5 項目（11)入室～扉閉・鍵施錠、(2)鍵施錠後〜大便器、(3)車い寸 〜手洗い、(4)手洗い〜鍵解錠、(5)扉開〜退出) の単位動作に区分し、 各単位動作別に分析、考察を行う。ここでは車い寸使用者の利用制 約の判断を求めるため車い寸の切り返し回数を考察の軸とした。

\section{3. 利用者検証概要}

\section{(1) 検証方法}

検証概要を表 2 に示す。検証方法は便房の入室から退出までの排 泄模擬動作を行い、カメラ撮影による利用動作を観察した。なお、 評価指標は「3．使える」、「2．使いにくい（使えないことはない）」 「1。使えない」の 3 段階評価とし、「3．使える」を各被験者が利 用可能なレベルと設定した。介助者が同行する場合は双方に確認し 評価が低い方を結論とした。

また、必要空間寸法の検討においては、間口方向（Y）を固定し、 奥行き方向 $(\mathrm{X})$ を $10 \mathrm{~cm}$ 間隔で可動壁を移動しながら、被験者が「 1 . 使えない」または「2．使いにくい」と「3．使える」と判断され た境界の空間寸法を確認した。「3, 使える」と判断された空間寸法 よりも広い場合は使えると判断し、「2．使いにくい」「1．使えな い」と判断された空間寸法よりも狭い空間寸法は使えないと判断し た（表 2 ）。その後、間口方向 $(\mathrm{Y})$ を $10 \mathrm{~cm}$ 間隔で変化させ、同様 の確認を行い間口方向（Y） $200 \mathrm{~cm}$ 未満×奥行き方向（X）200 cm未 満の範囲で確認した。

なお、既報 ${ }^{3)}$ では、大便器側面入口よりも大便器前方入口の方 がより広い空間寸法を必要とする結果であったため、本研究では条 件の厳しい大便器前方入口に限定し検証を行った（図 1 )。

\section{（2）検証環境}

検証環境を図 1 に示す。設備は大便器（前後長 $70 \mathrm{~cm}$ )、温水洗浄 便座付き、L型手すり（壁面からの距離 : $12 \mathrm{~cm}$ 、便器先端基準 : 縦 手すり位置 $25 \mathrm{~cm}$ 、便器芯一手すり芯 $35 \mathrm{~cm}$ )、可動式手すり水平ロッ ク機能付き（壁面から先端までの長さ $70 \mathrm{~cm}$ で大便器先端と同程度、 大便器芯一手寸り芯 $35 \mathrm{~cm}$ )、背もたれ、手洗器水石睑付き (奥行 $20.5 \mathrm{~cm}$ 、幅 $46 \mathrm{~cm}$ )、手動扉 - 鍵付き（出入口有効開口幅 $80 \mathrm{~cm}$ ）で設 定した。

また、便房の出入口は、袖壁を設けず、把手の設置高さは床から 手すり下端 $82 \mathrm{~cm}$ 上端 $125 \mathrm{~cm}$ とし、鍵の設置高さは床〜鍵中心まで $72 \mathrm{~cm}$ でレバー形状を使用した。把手及び鍵の壁からの距離は $9 \mathrm{~cm}$ と した。可動壁の可動範囲について、間口方向（Y）は可動手すりと 可動壁が干渉しない最小間口寸法 $95 \mathrm{~cm}$ とし、奥行き方向 $(\mathrm{X})$ は L 型手すりと手洗器が干渉しない最小奥行き寸法 $150 \mathrm{~cm}$ とした。

\section{（3）被験者属性と外出先でのトイレ利用状況}

被験者の選定は、外出時に常時車い寸で移動する、排泄を大型べ ッドではなく大便器を使用する、日常生活で大型の車い寸使用者を 対象とした。なお、検証では各被験者が実際に普段使用している車 い寸で評価を行った。被験者属性及び外出先でのトイレ利用状況を 表 3 に示す。
表 1 研究フロー

S T E P 1 。利用者検証によるトイレ利用動作の観察・分析 から必要空間寸法の明確化

S T E P 2 ．検証に参画した被験者との意見交換会により、 研究の狙い及び研究結果に対する利用者の評価 を確認

S T E P 3. 多くの車い寸使用者に利用可能な必要空間寸法 の検討

表 2 利用者検証概要

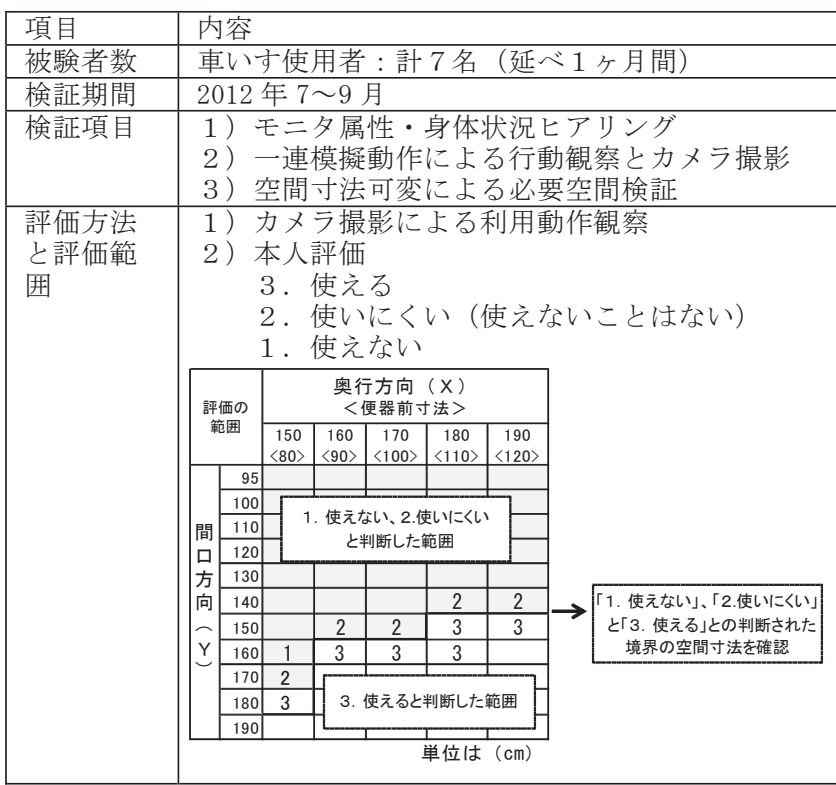

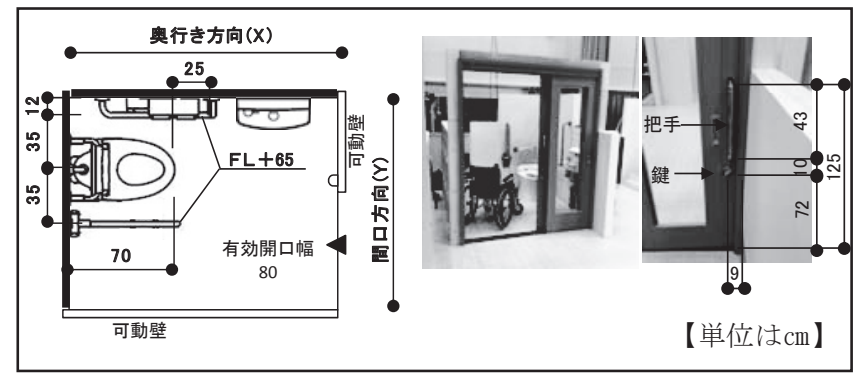

図 1 検証環境

表 3 被験者属性と外出先でのトイレ利用状況

\begin{tabular}{|c|c|c|c|c|c|c|c|c|c|c|c|c|c|c|}
\hline \multirow{3}{*}{ 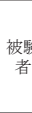 } & \multicolumn{12}{|c|}{ 被験者属性 } & \multicolumn{2}{|c|}{$\begin{array}{l}\text { 外出先での } \\
\text { 上イ利用 }\end{array}$} \\
\hline & \multirow{2}{*}{\begin{tabular}{|l} 
排泄行 \\
氶の自 \\
立度
\end{tabular}} & \multirow{2}{*}{$\begin{array}{l}\text { 車いす } \\
\text { の種類 }\end{array}$} & \multicolumn{2}{|c|}{\begin{tabular}{|c|c|c|} 
車いすサイス \\
$(\mathrm{cm})$
\end{tabular}} & \multirow{2}{*}{ 年齡 } & \multirow[b]{2}{*}{ 性別 } & \multirow[b]{2}{*}{ 疾患名 } & \multicolumn{5}{|c|}{ 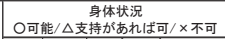 } & \multirow[b]{2}{*}{ 大便 } & \multirow[b]{2}{*}{ 小便 } \\
\hline & & & 全長 & 全塩 & & & & 步行 & 立位 & 立5 & 座位 & 座位姿劫 & & \\
\hline & & & & & & & & & & & & & & \\
\hline A & 自立 & 電動 & 126 & 63 & 63 & 男性 & 䝺䯣損傷 & $x$ & $x$ & $x$ & $\Delta$ & $x$ & 外出先飞は & 0 \\
\hline B & 自立 & 電動 & 112 & 59 & 63 & 男性 _ & 春骵性小児マヒ & $\Delta$ & $\Delta$ & $\Delta$ & 0 & 0 & 0 & 0 \\
\hline c & 自立 ～ & 電要 & 118 & 64 & 57 & 女性 & 脊䯙損傷 (腰椎) & $x$ & $\Delta$ & $\Delta$ & $\Delta$ & $\Delta$ & 0 & 0 \\
\hline & & & & & & & 多発性関節 & & & & & & & \\
\hline D & 自立 & 電動 & 118 & 67 & 53 & 男性 & $\begin{array}{l}\text { リウマチ } \\
\text { 機能傽四肢 }\end{array}$ & $\Delta$ & $\Delta$ & $x$ & $\Delta$ & 0 & O & 0 \\
\hline$E$ & 介助 & 電動 & 120 & 65 & 43 & 男性 & 难髉損傷 (C4-5) & $x$ & $x$ & $x$ & $\Delta$ & $x$ & 0 & 0 \\
\hline $\mathrm{F}$ & 介助 & 電動 & 104 & 67 & 50 & 男性 & 脳性マヒ & $x$ & $x$ & $x$ & 0 & 0 & 0 & 0 \\
\hline G & 介助 & 電動 & 149 & 62 & 40 & 男性 & 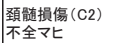 & $x$ & $x$ & $x$ & $x$ & $x$ & 外出先では & O \\
\hline
\end{tabular}


被験者は計 7 名で、 4 名が一連のトイレ動作を自立で行い、3 名 が介助者の付き添いを必要とした。全員が電動車い寸（内、1名が セニアカーを利用）を使用していた。年齢は 40〜63 歳、男性 6 名、 女性 1 名であった。外出先でのトイレ利用状況において、小便は全 員が行うが、日常生活で排泄調整を行っている頸髄損傷者の 2 名は 外出先で大便をしないようにしている。

本研究の被験者 7 名のうち被験者 $\mathrm{B}$ を除く 6 名は車い寸（自走 用・標準型）の外形寸法が車い寸サイズ（大・中・小型）別に規定 されていた旧・手動車いすの JIS 規格（JIS T9201：1987）の大型車 いすの外形寸法 (全長 $113 \mathrm{~cm}$, 全幅 $63 \mathrm{~cm}$ ) の全長・全幅の両方または 一方が同寸法以上のものである（図 2 - (1) 注 2)。また、うち 2 名 は最新の車い寸 J I S 規格 ${ }^{4}$ )である全長 $120 \mathrm{~cm}$ より大きい車い寸を 使用している（図 2-(2)）。

\section{4. 検証結果}

4-1.トイレ利用のポイントとなる動作の明確化

ここで紹介している動作例は、さまざまな身体状況の車い寸使用 のトイレ利用動作において、必要空間寸法を設定する上で特に必要 と判断された動作を抽出した。

\section{（1）大便器利用時の車いす位置について}

各被験者に対して、大便器へのアプローチ方法で最も利用しやす い車い寸の位置（側方・直角・斜め前方・正面）であるか、それ以 外の残りの 3 つ車い寸位置で利用可能かの確認を行った。大便器 利用時の車いす位置と大便器利用時のポイントを表 4 に示す。

\section{a. 大便器利用時に車いすの位置が限定される場合}

被験者 $\mathrm{A}, \mathrm{B}, \mathrm{C} 、 \mathrm{G} の 4$ 名は大便器利用時の車い寸位置が制限 されることが確認された。被験者 $\mathrm{A} 、 \mathrm{G}$ の 2 名は留置カテーテルを 使用していることから、大便器利用時は留置カテーテルの管が届き、 かつ、手が届く「側方、直角」の位置に車い寸をとめた。（写真 1$)$ 。

また、被験者Bは乗り降りを横から行うセニアカーに乗っている ため、「斜め前方、正面」にはとめなかった。被験者 C は L 型手すり を握って車いすから立ち上がり大便器に移乗するため、L型手すり が届かない「側方」の位置は利用できなかった（写真 2 )。

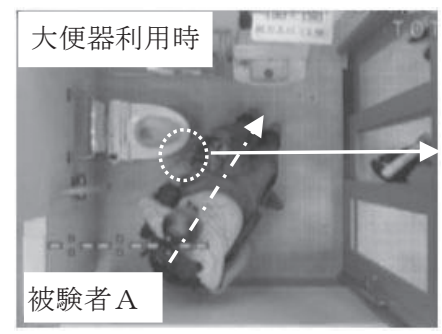

車いすと便器を近づけて 留置カテーテルの管が届 き、手が大便器に届く位置 に車いすをとめる

写真 1 被験者 $\mathrm{A}$ の大便器利用時の車い寸位置（自立）
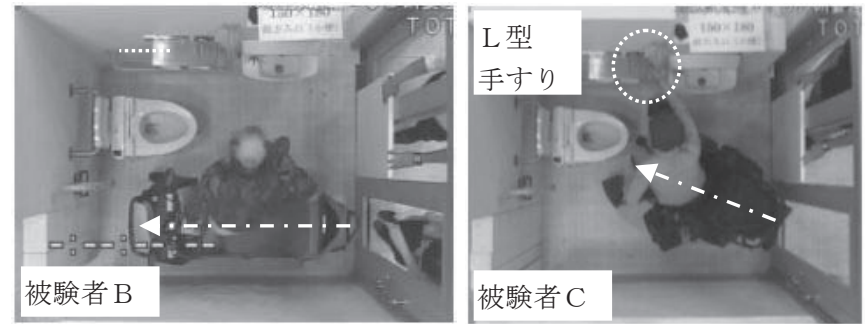

写真 2 被験者 B, C の大便器利用時の車い寸位置（自立）

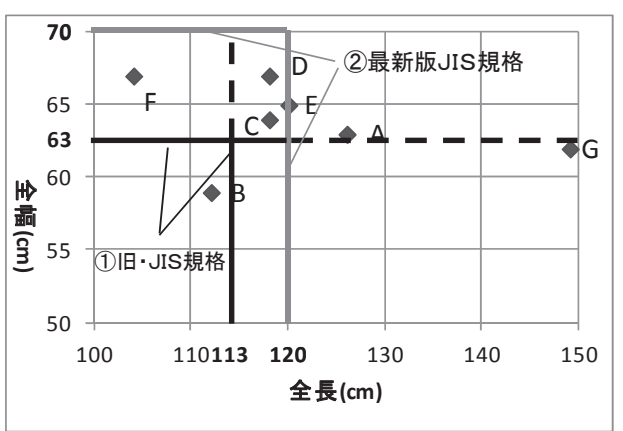

図 2 被験者の車い寸サイズ

表 4 大便器利用時の車いす位置と大便器利用時のポイント

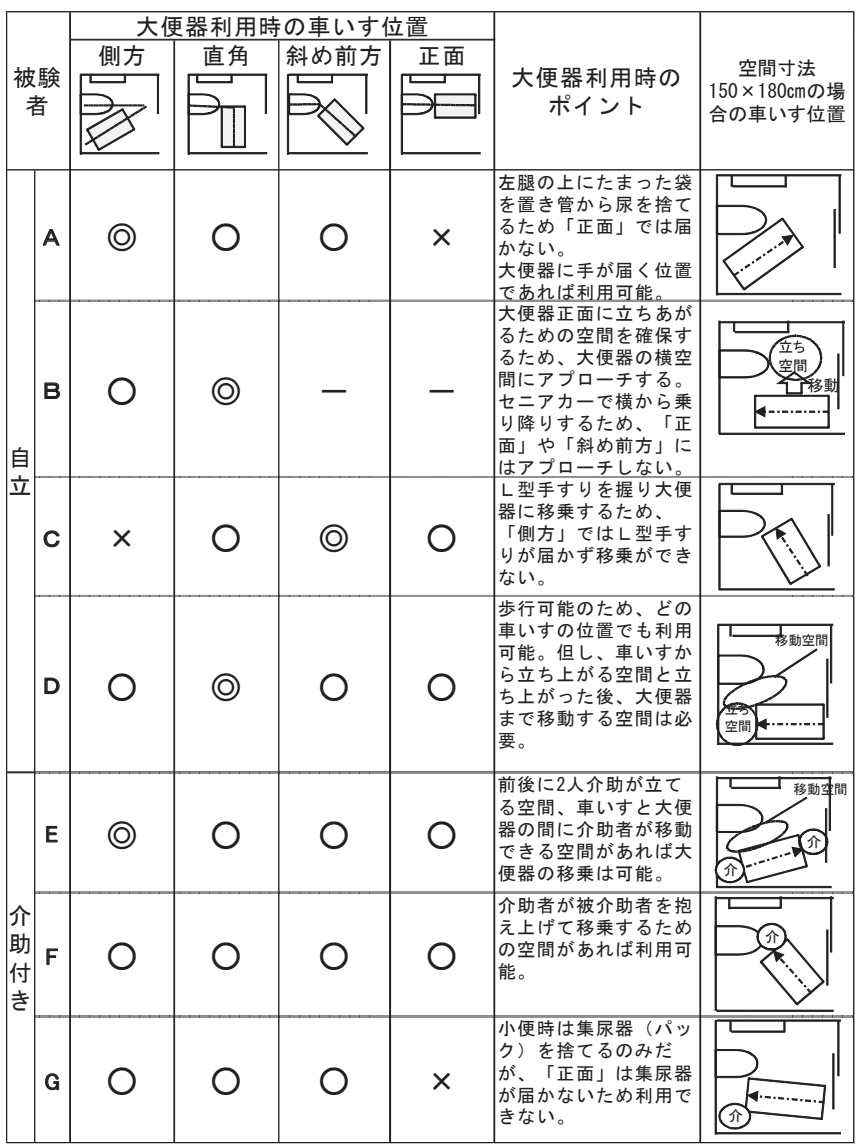

（）：最も利用しや寸い位置 ○：利用が可能な位置 $\times:$ 利用が不可能な位置 - : 対象外

\section{b. 大便器利用時に車いすの位置が限定されない場合}

被験者 D は車いすから立ち上がった後は歩行可能であったため、 車い寸から立ち上がる空間及び立ち上がり後の大便器までの移動空 間が確保されていれば車いすの位置は限定されなかった。

また、介助者が付き添う被験者 $\mathrm{E}, \mathrm{F}$ は介助者が移乗及び排泄サ ポートをしていることから、介助者が便房内で移動できる空間が確 保されていれば車いすの位置は限定されなかった。

以上から、大便器の利用は全員が利用可能であった「直角」の位 置を中心として、「側方、斜め前方」の範囲に車い寸がとめられる空 間を確保することで、自立、介助付きともに大便器の利用が概ね可 能となることが確認された（図 3 。網掛け部分）。 


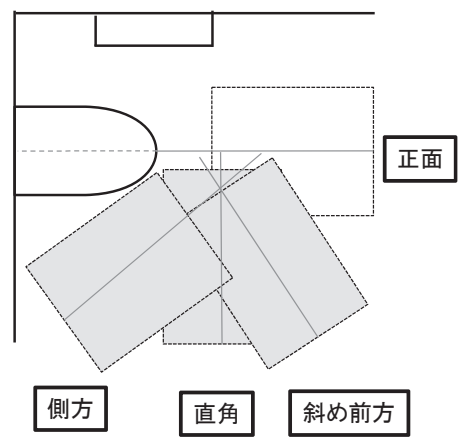

図 3 大便器と車い寸の位置関係

\section{（2）トイレ利用時の車いすの方向転換について}

各被験者の入室から退室までの一連のトイレ利用動作（1)入室〜 屝閉・鍵施錠、(2)鍵施錠後〜大便器、(3)車い寸〜手洗い、(4)手洗い 〜鍵解錠、(5)扉開〜退出）を単位動作ごとに車いすの切り返し回数 をまとめたものを図 4 に示す。ここで示している空間寸法は本人評 価において「3．使える」と判断した中で最も切り返し回数が多か った空間寸法を抽出した。

被験者Aを除いた全員が、一連のトイレ利用動作において車いす の切り返し回数は 5 回程度で使えると判断している。トイレ利用時 は緊急性を要する場面もあるため、切り返しが多いとトイレの利用 時間もかかり、気を使うとの意見も聞かれた。

\begin{tabular}{|c|c|c|c|c|c|c|c|c|}
\hline & \multirow{2}{*}{\begin{tabular}{|l} 
被験者が使えると判断した \\
空間寸法 \\
間口方向 ×奥行き方向 \\
(面積)
\end{tabular}} & \multicolumn{5}{|c|}{$\begin{array}{c}\text { 各単位動作別の } \\
\text { 切り返し回数 }\end{array}$} & \multirow[b]{2}{*}{$\begin{array}{l}\text { 切 } \\
\text { l } \\
\text { 返 } \\
\text { L } \\
\text { 回 } \\
\text { 数 } \\
\text { 合 } \\
\text { 計 }\end{array}$} & \multirow[b]{2}{*}{$\begin{array}{l}\text { 退 } \\
\text { 室 } \\
\text { 時 } \\
\text { の } \\
\text { 向 } \\
\text { き }\end{array}$} \\
\hline & & \begin{tabular}{|c|}
1 \\
$\lambda$ \\
入室 \\
s \\
扉 \\
閉 \\
- 鍵 \\
施 \\
錠 \\
\end{tabular} & \begin{tabular}{c|c} 
(2) \\
鍵 \\
施 \\
錠 \\
後 \\
大 \\
便 \\
器
\end{tabular} & $\begin{array}{l}\text { (3) } \\
\text { 車 } \\
\text { い } \\
\text { す } \\
\text { s } \\
\text { 手 } \\
\text { 洗 } \\
\text { い }\end{array}$ & \begin{tabular}{|c|}
4 \\
手 \\
洗 \\
W \\
s \\
鍵 \\
解 \\
錠 \\
\end{tabular} & $\begin{array}{l}\text { (5) } \\
\text { 扉 } \\
\text { 開 } \\
\text { 退 } \\
\text { 出 }\end{array}$ & & \\
\hline \multirow{4}{*}{ 自 } & A: $140 \times 190\left(2.66 \mathrm{~m}^{2}\right)$ & 4 & 8 & 0 & 5 & 6 & 23 & 前進退室 \\
\hline & B: $120 \times 150\left(1.8 \mathrm{~m}^{2}\right)$ & 0 & 0 & 0 & 0 & 0 & 0 & 後進退室 \\
\hline & C: $150 \times 180\left(2.7 \mathrm{~m}^{2}\right)$ & 1 & 0 & 0 & 0 & 1 & 2 & 後進退室 \\
\hline & $D: 120 \times 190\left(2.28 \mathrm{~m}^{2}\right)$ & 0 & 0 & 0 & 0 & 0 & 0 & 後進退室 \\
\hline \multirow{3}{*}{$\begin{array}{l}\text { 介 } \\
\text { 助 }\end{array}$} & $E: 170 \times 150\left(2.55 \mathrm{~m}^{2}\right)$ & 0 & 5 & 0 & 0 & 0 & 5 & 後進退室 \\
\hline & $F: 150 \times 160\left(2.4 \mathrm{~m}^{2}\right)$ & 0 & 0 & 0 & 0 & 0 & 0 & 後進退室 \\
\hline & G: $160 \times 170\left(2.72 \mathrm{~m}^{2}\right)$ & 0 & 1 & 0 & 0 & 1 & 2 & 後進退室 \\
\hline
\end{tabular}

図 4 各被験者が「3. 使える」と判断した空間寸法、動作と車 いすの切り返し回数及び退室時の車いすの向き

\section{(1)入室 扉閉 · 鍵施錠}

被験者 $\mathrm{A}$ は入室〜扉閉・鍵施錠において車いすの切り返しが 4 回 発生している。入室後に扉を閉めるために方向転換を行い、さらに 鍵施錠のために再度方向転換を行うという動作が確認された。扉

閉・鍵施錠のための車いすの方向転換においては大便器前方空間を 使用している (写真 3 )。

被験者 B、Cは、入室後に車い寸の方向転換をせず、体をひねり ながら手を後ろに伸ばし扉閉・鍵施錠を行ったため切り返しはほと んど発生していない (写真 4 )。また、介助者が付き添う場合は全員 が扉閉・鍵施錠を介助者が行っており、同様に切り返しは発生して いないことから方向転換を必要としない方は狭くても利用可能であ
った（写真 5 )。

入室〜扉閉・鍵施錠は自立で行う場合、鍵の施錠時に後ろ向きで できない方が前〜横向きで鍵施錠を行うために車いすの方向転換を 必要とする方が最も空間を広く必要とすることが再確認された。

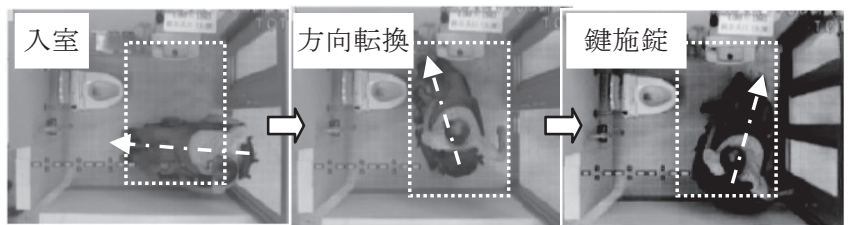

写真 3 被験者 $\mathrm{A}$ の扉閉・鍵施錠（自立：前〜横向きで鍵施錠）

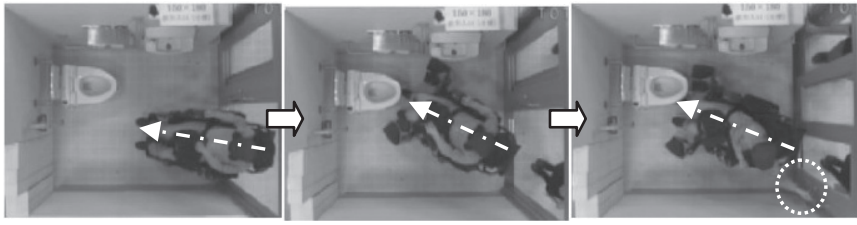

写真 4 被験者 $\mathrm{C}$ の扉閉・鍵施錠（自立：後乃向きで鍵施錠）

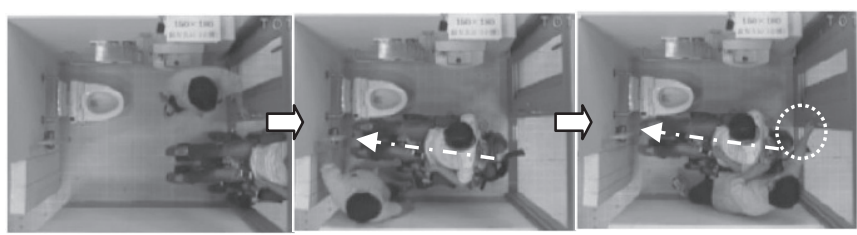

写真 5 被験者 $\mathrm{G}$ の扉閉・鍵施錠（介助者が鍵施錠）

\section{(2)鍵施錠後 大便器}

被験者 $\mathrm{A} 、 \mathrm{E}$ は 5 ～8 回、車い寸の切り返しが発生しており、一 連の動作の中で最も切り返し回数が多いことが確認された。2名の 共通として $4-1$ （1）で述べた大便器利用時の車い寸位置が「側 方」であったことから、鍵施錠後に大便器前方空間を使用しながら 車い寸の方向転換を行う動作が生じたためでであった（写真 6 )。

一方、自立の被験者 B、Dの 2 名は自立歩行が可能であったこと から、便房内で車い寸をとめた後、車いすから立ち上がり移動して 大便器への移乗を行い車い寸の切り返しは発生しなかった。

また、介助者が付き添う F、Gの 2 名は入室後〜大便器の利用時 まで車いすをほとんど移動していないことから、車いすの切り返し は発生しなかった。

鍵施錠後〜大便器は、大便器利用時の車い寸位置が「側方」にと める方が車い寸の方向転換に切り返しが多く発生し、大便器前方空 間を広く必要とすることが確認された。

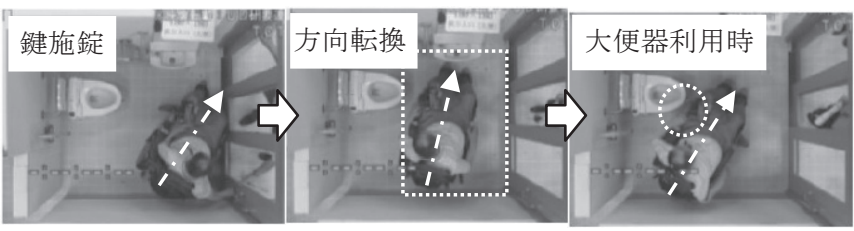

写真 6 被験者Aの鍵施錠後〜大便器位置までの移動

\section{(5)扉開・退室}

被験者 $\mathrm{A}$ は車い寸の切り返し回数が 6 回発生している。前進退室 する際に車い寸のフットレストが扉に当たってしまい、退室できな かったため、さらに車い寸の方向転換で切り返しを必要とした（写 
真 7 )。退室時の向きについて、自立の方は利用した便房の広さによ って方向転換ができない場合は「後進退室」でも利用可能であると 判断された。

被験者 $\mathrm{A}$ を除く全員は後進退室により便房内での車いすの切り返 しをする必要がほとんどなくそのまま退室することができた（写真 8 )。介助者が付き添う場合は、全員が「(1)入室〜扉閉・鍵施錠」と 同様に介助者が扉を開けており、後進退室時の誘導や見守りができ るため、後ろ向きでも良いという意見がほとんどであった。

扉開・退室は「前進退室」をする際、車い寸の方向転換のために 大便器前空間を広く必要とすることが再確認された。

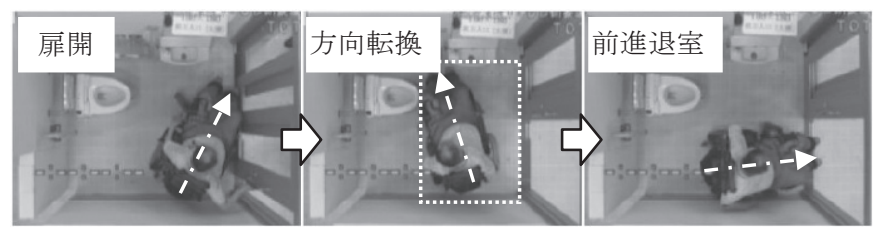

写真 7 被験者 $\mathrm{A}$ の扉開・退室（自立：前進退室）

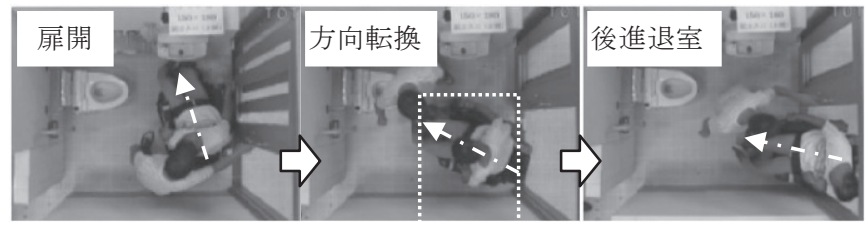

写真 8 被験者 $\mathrm{F}$ の扉開・退室（介助付き：後進退室）

4-1の結果から、トイレ利用動作のポイント（条件）を以下に示 す。

\section{$<$ 自立 $>$}

(1)扉の開閉・鍵の施錠・解錠ができる。

(2)大便器の利用に配慮し、大便器横（斜め前方、直角、側方）に 車い寸をとめることができる。

(3)便房内で方向転換ができる

<介助付き $>$

(1)介助者が扉の開閉・鍵の施錠・解錠ができる。

(2) 被介助者が大便器に接近でき、介助者が移乗・排泄サポートを できる。

(3)便房内で方向転換ができる

車い寸使用者用便房の必要空間寸法の設定においては、自立、介 助付きともに各 3 つの条件を満たすことであり、大便器の利用に配 慮して大便器横（斜め前方、直角、側方）に車い寸がとめられる「間 口方向 $(\mathrm{Y}) 」 を$ 確保すること、車い寸の方向転換ができる「大便器 前寸法 $\times$ 間口方向 $(\mathrm{Y})$ 」を確保することで多くの車いす使用者に利 用可能となることが確認された。

\section{4-2. トイレ利用動作のポイント（条件）を満たす必要空間寸法} 被験者 7 名に対して、4-1 で導き出された多くの車い寸使用者 が利用可能な車い寸使用者用便房に求められる 3 つの条件を満たし た被験者の割合を図 5 に示す。

自立者は、(Y) $150 \mathrm{~cm} \times(\mathrm{X}) 180 \mathrm{~cm} 、 160 \mathrm{~cm} \times 160 \mathrm{~cm}$ の 2 つの空間 寸法について全員が利用可能であった。また、介助付きは $150 \mathrm{~cm} \times$ $180 \mathrm{~cm} 、 160 \mathrm{~cm} \times 170 \mathrm{~cm} 、 170 \mathrm{~cm} \times 160 \mathrm{~cm}$ の 3 つの空間寸法について 全員が利用可能であった。

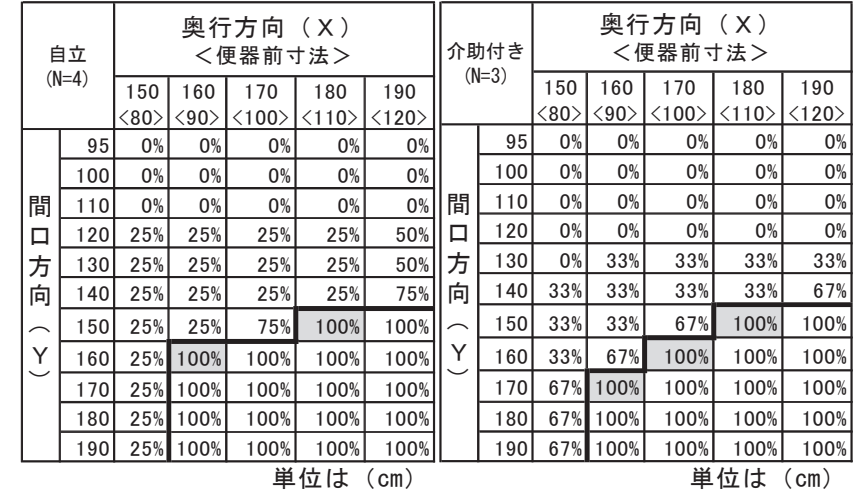

図 5

トイレ利用動作を満たした被験者の割合（自立・介助付き）

\section{5. 検証に参画した被験者との意見交換会による利用者評価}

2012 年 10 月、11月の 2 回に分けて、利用者検証に参加した被験 者と意見交換会を実施した。意見交換会では、(1)研究結果の妥当性、 及び(2)車いす使用者用便房の標準的な寸法 $200 \mathrm{~cm} \times 200 \mathrm{~cm}$ 程度の確 保が困難な小規模施設や既存施設の改修において、ひとまわり小さ い車いす使用者用便房を提案することが可能であるか、の 2 点につ いて利用者の評価を行った。主な意見内容を表 5 に示す。

\section{表 5 意見内容}

<小規模施設・既存施設の改修への展開に関する意見内容 $>$

・自宅の近くにできたコンビニエンスストアに広くはないが車 いすで使える便房があり、便房内に入ってなんとか切り返し をして利用できた。使いやすいとは言えなかったがあること がうれしい。また、美容室など長時間いる時にトイレが行き たくなるのを我慢することもあって困る。（被験者 C : 脊髄 損傷・57 歳・車い寸全長 $118 \mathrm{~cm}$ )

・トイレ利用には便房内の寸法だけではなく、便房外の通路幅 も重要であるため今後確認をしてほしい。（被験者 C : 春髄 損傷・ 57 歳・車い寸全長 $118 \mathrm{~cm}$ )

・最近できた大規模施設でも限られた空間に乳幼児連れやオス トメイトの機能を無理やり設置してしまい、車い寸の動作空 間がより狭くなる。場合によって使えないトイレも出てくる ためできれば一般トイレに機能を移してほしいが、1 箇所し かつくれないような施設であれば車い寸動作空間を確保し た上で設置するなどの配慮が必要。(被験者 $\mathrm{A}$ ：頸髄損傷・ 63 歳・車い寸全長 $126 \mathrm{~cm}$ )

$<$ 検証結果に関する意見内容 $>$

・実験として行った時は使えると判断したが、実際のトイレで 利用できるかは別。今回の研究は車い寸の切り返しに着目し た空間寸法の設定であるため、切り返し回数がどの程度許容 されているかを数值化してほしい。(被験者 A)

・空間寸法の設定において特に重要なのは、建具（扉・鍵）の 種類・形状によっても車いすの切り返しの回数が異なる。今 後は建具も含めた検討をしてほしい。（被験者 D：多発性関 節リウマチ上下肢四肢機能障害・53 歳・車い寸全長 $118 \mathrm{~cm})$

(1)検証結果の妥当性については、本研究で利用可能と判断された 便房の広さにおける便房内での車いすの切り返し回数について、ト イレ利用時は緊急性を要する場面があり、切り返しが多いとトイレ の利用時間がかかることやストレスがある（気を使う）という理由 
から本研究では 5 回程度としたことについて特に反論はなかった。 その理由としては一般的な利用経験の中でも少なくとも同程度の切 り返し行為が行われているためと考えられる。実験と実使用におい ては便房内に設置される設備やレイアウトの条件によっても異なり、 特に、扉の種類や把手や鍵の位置 - 形状によっても車いすの切り返 し回数が異なるとの意見であった。

本研究においては、便房の出入口は「手動式の扉」、また既存の便 房で見られ一部の車い寸使用者から利用上の問題を指摘されている 「便房の入隅に近い位置に把手・鍵（袖壁なし）」という条件で行っ たが、電動式の扉へ変更、鍵・把手の位置や形状を工夫することで、 やや小さめの車い寸使用者用便房でも車い寸の切り返し回数がより 少なくなり、利用可能となる可能性も見出せた。

(2)車い寸使用者用便房の標準的な寸法 $200 \mathrm{~cm} \times 200 \mathrm{~cm}$ 程度の確保 が困難な小規模施設や既存施設の改修などにひとまわり小さい車い 寸使用者用便房が普及されることについては、現状、車い寸使用者 用便房がない施設において、200 cm × $200 \mathrm{~cm}$ 程度の空間確保が困難で あることは被験者も理解しており、ひとまわり小さい車い寸使用者 用便房のみであってもトイレ利用が可能であれば、気兼ねなく施設 が利用できることが確認された。

\section{6. 結論}

本研究では、自立、介助付きを含めた車い寸使用者が利用可能な 便房の必要空間寸法を導き出すためのポイントとなる主な行為は、

(1)車い寸使用者（及び介助者）が便房内に入り、扉の開閉・鍵の

施錠・解錠するための車いすの方向転換

(2)大便器利用のための接近・移乗 (介助が移乗・排泄サポート) ができることであり、トイレ利用動作に影響する空間寸法は「大便 器前寸法 $\times$ 間口方向（Y)」が重要であることを見出した。

トイレ利用時は緊急性を要する場面があり、切り返しが多いと卜 イレの利用時間がかかることやストレスがある（気を使う）が便房 内での車いすの切り返し回数は 5 回程度であれば、特段のストレス なく利用可能と判断された。自立・介助付きともに、便房の広さに よって車い寸の切り返し回数を減らす工夫として、「後方退室」によ って利用することが確認された。

多くの車い寸使用者に利用可能な必要空間（内法）寸法は次のい ずれかである。(図 6、7 )

1) $150 \mathrm{~cm} \times 180 \mathrm{~cm}$ : 便器前寸法 $110 \mathrm{~cm}$

2) $160 \mathrm{~cm} \times 170 \mathrm{~cm}$ : 便器前寸法 $100 \mathrm{~cm}$

3) $170 \mathrm{~cm} \times 160 \mathrm{~cm}$ : 便器前寸法 $90 \mathrm{~cm}$

大便器横空間は、間口方向 $(\mathrm{Y}) 150 \mathrm{~cm}$ 以上を確保することで利用 可能となる。また、160 cm、170 cm と間口方向 $(\mathrm{Y})$ を $10 \mathrm{~cm}$ 広げる ことで、大便器前寸法が $10 \mathrm{~cm}$ 小さくても利用可能となることから、 車い寸の方向転換及び、大便器利用のための接近・移乗の必要空間 寸法である、「大便器前寸法 $\times$ 間口方向 $(\mathrm{Y}) 」$ は密接に関わってい ることが確認された。

なお、多様な被験者の範囲想定をどこまですれば良いか、円滑さ についての定義も利用者自身が不確定であり、自立と介助付きでも 移動動作に大きな差があることからさらなる検討が必要と考えてい る。大型車い寸使用者の特性としては、障害の多様性、上肢の困難 さなどから要介助が多いことがあげられる。今後、空間寸法だけで
なく、設備機器のレイアウトや建具・鍵のデザイン工夫等、より包 括的に利用しや寸い環境設備、機器整備の追求が必要である。

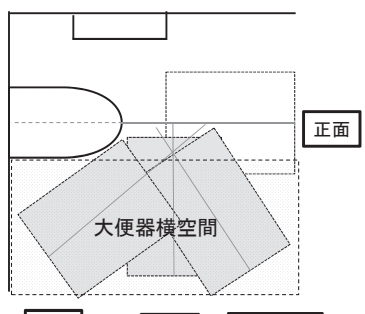

側方

直角 斜也前方

図 6 大便器の利用に配慮した 大便器横空間の確保

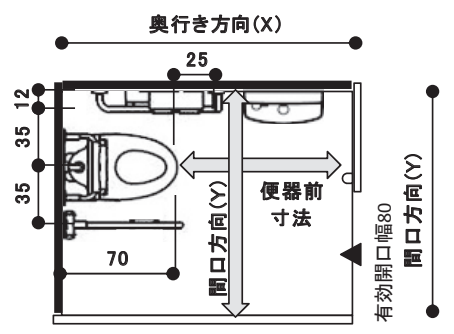

図 7 車い寸使用者用便房の 必要空間寸法

\section{謝辞}

本調查を実施するに当たり、協力いただいた被験者の皆さまに心よ り感謝いたします。

\section{注}

注 1 ) 写真 1 〜写真 8 に記載している矢印等の意味について

(1) 矢印付き 1 点鎖線 $(-\cdots)$ ：中心線の矢印は車い寸の向き及び中心線 (2)四角点線（1.... (3)円点線（）：トイレ利用動作に影響があった部分

注 2 ) 本研究は旧・JIS と最新版・JIS の双方から確認し、現在の汎用サイズ から「大型車い寸使用者」を以下のように設定した。

車い寸（自走用・標準型）の外形寸法の全長・全幅の両方または一方が、 車いすサイズ（大・中・小型）別に規定されていた旧・手動車いすの JIS 規格（JIS T9201：1987）の大型車い寸の外形寸法（全長：113cm ただし、 フットレストの奥行きを $15 \mathrm{~cm} 、$ タイヤの直径を 26 インチとして算出、全 幅：63cm）以上の車い寸を使用している人。

\section{参考文献}

1) 国土交通省：高齢者、障害者等の円滑な移動等に配慮した建築設計標準, 発行人にやさしい建築・住宅推進協議会, 平成 24 年度

2 ）国土交通省 総合政策局安心生活政策課: 多様な利用者に配慮したトイレ の整備方策に関する調查研究 報告書, 2012.3

3 ）高塩康洋，河野裕之, 前橋信之, 高橋儀平：車い寸使用者のトイレ利用動 作と空間寸法に関する研究, 日本建築学会計画系論文集第683号, pp6572, 2013. 1

4）日本規格協会：日本工業規格 手動車い寸（JIS T 9201：2006, JIS T 9201-1987)

5 ）日本規格協会：日本工業規格 電動車い寸（JIS T 9203:2010, JIS T 9203-1987)

6 ）竜口隆三, 高橋儀平, 田村房義 : 簡易型多機能トイレの最小空間寸法に関 寸る研究, 日本建築学会計画系論文集第 640 号, pp. 1365-1370, 2009.6

7 ) 竜口隆三, 高橋儀平, 田村房義 : 車いす使用者等の大便器まわりの手すり の適正化に関寸る研究, 日本建築学会計画系論文集第634号, pp. 2623$2628,2008.12$

8 ）赤田義史, 小松修司, 高塩康洋, 江藤祐子 : 公共トイレにおける車いす使用 者の利用実態に関する研究 その 1 多機能トイレにおける車い寸使用者 実態調査, 日本建築学会大会学術講演梗概集 E-1, pp. 679-680, 2011

9 ）小松修司, 高塩康洋, 赤田義史, 江藤祐子：公共トイレにおける車い寸使用 者の利用実態に関する研究 その 2 車い寸使用者用便房の多機能化改修 に関する実態調査, 日本建築学会大会学術講演梗概集 E-1, pp. 681-682, 2011

10）高塩康洋, 小松修司, 赤田義史, 江藤祐子 : 公共卜イレにおける車い寸使用 者の利用実態に関寸る研究 その 3 多機能トイレにおける車い寸使用者 の大便器移乗に関寸る調査, 日本建築学会大会学術講演梗概集 E- $-1, p p$. 683-684, 2011

11）中島 佐智子: 多目的トイレにおける重度肢体不自由者の利用上の問題点 についてその 2 多目的トイレ実態調査結果の考察, 日本建築学会大会学 術講演梗概集 E-1, pp. 957-958, 2005 